\title{
京都大学 生存圏研究所 生物機能材料分野
}

矢 野 浩 之*・師岡 敏朗*.田中文男*

\section{1. 生存圏研究所}

京都大学生存圈研究所は, 人類の生存に必要な領域と空 間，すなわち人間生活圈，森林圈，大気圈，および宇宙空 間圈を「生存圈」としてグローバルにとらえ，その「科学 的診断と技術的治療」に関する革新的学際領域の開拓と発 展を目指して, 平成 16 年 4 月 1 日に京都大学木質科学研 究所と宙空電波科学研究センターが再編・統合して出来た 新しい研究所である。

生存圈研究所では, 以下の 4 つのミッションを研究の柱 としている.

ミッション 1 : 環境計測・地球再生

地球大気の観測とその技術，木質遺伝子生化学研究，木 質資源の有効利用などの研究を深化させて, 生存圈環境の 現状と変動に関する認識を深めるとともに，環境を保全し つつ持続的に木質資源を蓄積・利活用するシステムの基盤 の構築をめざす.

ミッション $2:$ 太陽エネルギー変換・利用

宇宙太陽発電所の研究，木質バイオマスのエネルギー・ 化学資源変換の研究を進展させ，化石資源の消費量を減ら し太陽輻射㧍よびバイオマスエネルギーを利用した再生産 可能なエネルギー変換利用による持続的な社会の構築をめ ざす.

ミッション $3:$ 宇宙環境・利用

宇宙空間プラズマの研究を発展させ, 地球周辺の宇宙空 間の環境の探査とその探査技術の開発および宇宙自然環 境・飛翔体環境の定量解析, さらにこれらの環境下の木質 素材の開発利用などの研究で宇宙空間を 21 世紀の人類の 新たな生活圈に拡大していく研究基盤の構築をめざす.

ミッション 4 : 循環型資源・材料開発

生物資源のなかでも再生産可能かつ生産量の多い木質資 源に関する研究を深化・発展させ, 生産, 加工・利用, 廃 裹・再利用に至る各段階での低環境負荷型要素技術開発を 行って，持続的循環型社会を実現するための木質資源の循 環システムの構築をめざす.

* Yano, Hiroyuki/Morooka, Toshiaki/Tanaka, Fumio 京都大学 生存圈研究所 生物機能材料分野 宇治市五ヶ庄（611-0011）

2005.2.2 受理

\section{2. 分野の概要}

生物機能材料分野は，主としてミッション 4 に関わって いる. 現在, 矢野教授, 師岡助教授, 田中助教授に加え, 博士研究員 2 名, 博士課程 4 名, 修士課程 3 名で, 木質を 初めとする生物材料の構造と物理的機能との関係について 解析を行うとともに，それに基づいた先導的な生物材料加 工技術，製造技術の開発を進めている.

現在の主なテーマは，セルロースナノファイバーの製造 技術開発とそれを用いたナノコンポジットの創成（矢野), 樹木の樹皮夕ンニンの成型物原料としての利用 (矢野), 水分と熱が関与する木材レオロジー（師岡），機能性多糖 の分子設計 (田中), 多糖及び多糖誘導体の構造解析（田 中）等である。

\section{3 . 当分野の研究内容}

\section{1 セルロースナノファイバー}

セルロースミクロフィブリル（図 1）は，植物細胞壁（植 物繊維）の $50 \%$ 以上を占める骨格物質で，伸びきり鎖結 晶からなる幅 $4 \mathrm{~nm}$ のナノファイバーである。その弾性率, 強度はそれぞれ $140 \mathrm{GPa}$ および $3 \mathrm{GPa}$ に達する。これは 代表的な高強度瀻維，アラミド繊維（ケブラー）に等しく， ガラス瀻維よりも高弾性である。ささらに，その熱膨張係数 は $0.1 \mathrm{ppm} /{ }^{\circ} \mathrm{C}$ と石英ガラスに匹敵するほど低い．加えて, セルロースミクロフィブリルは, 地球上で最も大量に生産

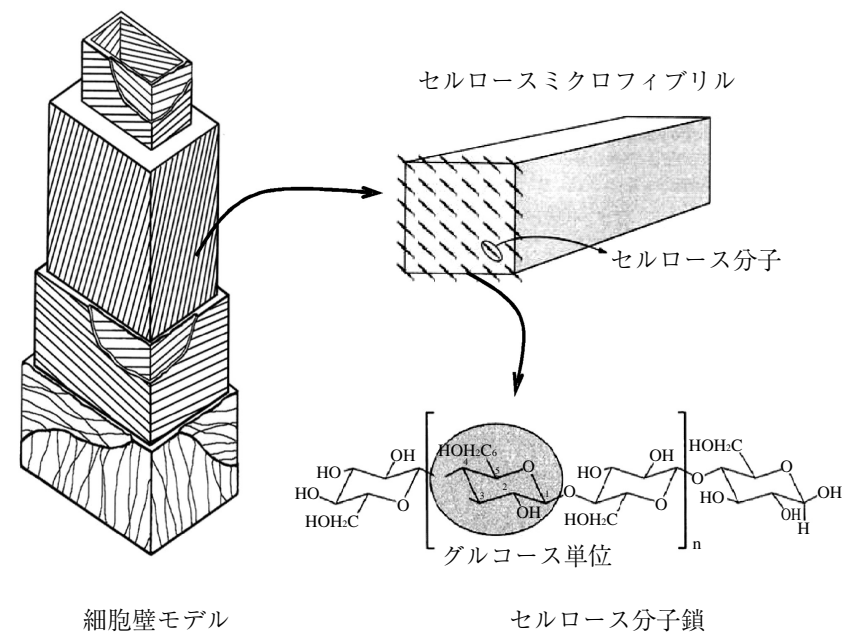

図 1 木材の細胞壁構造とセルロースミクロフィブリル 
されている持続型資源 (推定蓄積量：1 兆トン)で，生産・ 廃棄に関する環境負荷が極めて小さい.

矢野らは，七ルロースミクロフィブリルを基本構成要素 としたナノコンポジットについて研究を進めている．以下 に述べるように，セルロースミクロフィブリルが数本ある いは数十本の束となったセルロースナノファイバーで強化 した複合材料について, 興味深い強度的特性, 熱機械的特 性, 光学的特性が見出されており, 植物繊維からセルロー スナノファイバーを安価に製造する技術の開発は，当分野 の重要なテーマの一つとなっている.

\section{2 ミクロフィブリル化セルロース（MFC）を用いた 繊維強化材料}

MFC（Microfibrillated Cellulose）は，植物繊維（パル プ）をミクロフィブリルのオーダーにまで機械的に解繊し たもので，マイクロからナノレベルまでのクモの巣状ネッ トワークが特徴である (図 $2, \times 2000$ 倍).

MFC にフェノール樹脂（PF）を 10-20\% 複合した MFC $-\mathrm{PF}$ 複合成型物は, パルプ-PF 複合成型物に比べ破壊ま でのひずみが大きく増大し，曲げ強度は $400 \mathrm{MPa}$ 近くに まで達する。これは，軟鋼やマグネシウム合金に匹敵する 值である，曲げヤング率は，20 GPaである， MFC 成型物 は, 密度 $1.5 \mathrm{~g} / \mathrm{cm}^{3}$ であり, 軟鋼 (密度 $\left.7.8 \mathrm{~g} / \mathrm{cm}^{3}\right)$, マ グネシウム合金（密度 $1.8 \mathrm{~g} / \mathrm{cm}^{3}$ ) に比べ軽量である.

カーボンニュートラル, 生分解性といった環境調和性も $\mathrm{MFC}$ の重要な特性である。この特性を生かした材料とし て，スラリー状の $\mathrm{MFC}$ （水分 $90 \%$ ）に酸化デンプンをバ インダーとして MFC 乾燥重量に対して $2 \%$ 添加し, 脱水, 熱圧した成型物（MFC-Starch）を製造した。成型物の曲 げヤング率は $12.5 \mathrm{GPa}$ であるが, 破壊ひずみがデンプン 無添加の時の倍以上にまで増大し, 曲げ強度は $320 \mathrm{MPa}$ に到達する。また，MFCとバイオプラスチック繊維（ポ リ乳酸：PLA）を水中で混抄し（MFCと PLAの重量比
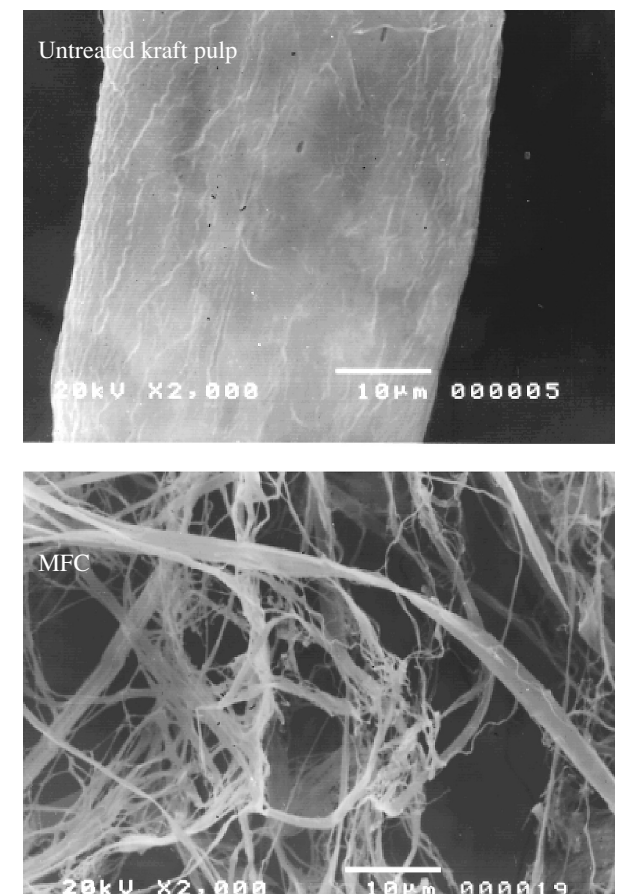

図 2 クラフトパルプとそれを解繊したミクロフィブリル 化セルロース（MFC）
は $7: 3)$, 成膜後, 積層熱圧した成型物（MFC-PLA）で

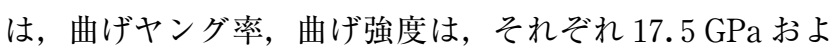
び $270 \mathrm{MPa}$ に達する.これらの材料の曲げ変形特性を図 3 に示す。いずれも密度 : $1.4 \mathrm{~g} / \mathrm{cm}^{3}$ でマグネシウム合金 （Mg alloy）に近い強度を示す. 低環境負荷型の高強度成 型材料として, モバイル型コンピュータや携帯電話の筐体 (ケーシング), 自動車部材等への応用が考えられる.

\section{3 ナノファイバー繊維強化透明材料}

携帯電話やモバイルコンピュータといった情報関連機器 の急激な進歩に伴い，ディスプレイ材料や光通信関連部材 に用いられる透明材料には，フレキシブルでかつ低熱膨張， 高強度といった，既存のガラスやプラスチックでは得られ ない特性が求められる様になっている，光の波長に対して 十分に小さなコンポーネントは光散乱を生じないことから, これまで，ゾル・ゲル法による低熱膨張の無機材料とプラ スチックとの複合化やエレクトロンスピニング法で作成し たナノファイバーによるプラスチックの補強などが検討さ れてきたが，いずれも，十分な特性は得られていない.

矢野らは，バクテリア (䣷酸菌, Acetobacter Xylinum) が産出するセルロースミクロフィブリル束が(図 4), 幅 50 $\mathrm{nm}$ と，可視光波長に対して $1 / 10$ のサイズで，かつ，高 強度, 高弾性, 低熱膨張であることに着目して, バクテリ アセルロースと透明樹脂との複合について検討している.

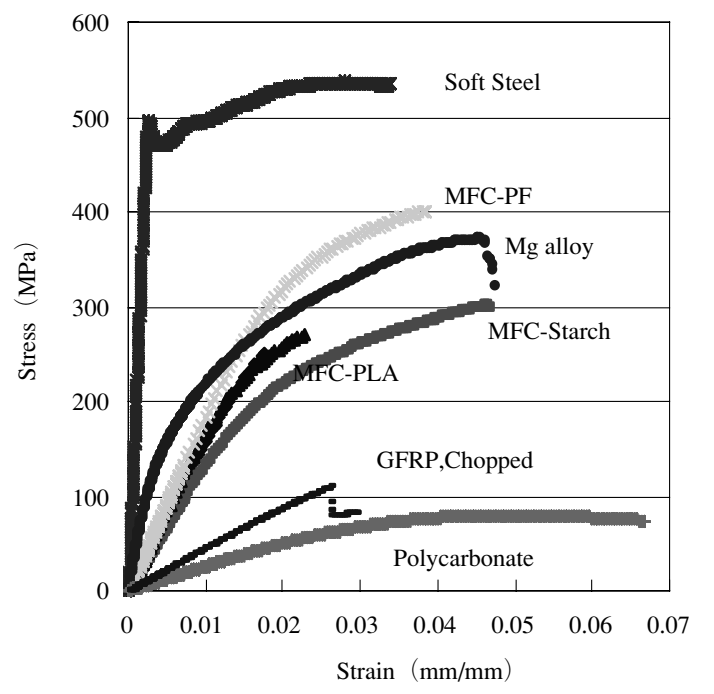

図 $3 \mathrm{MFC}$ 成形材料と他材料の曲げ変形特性の比較

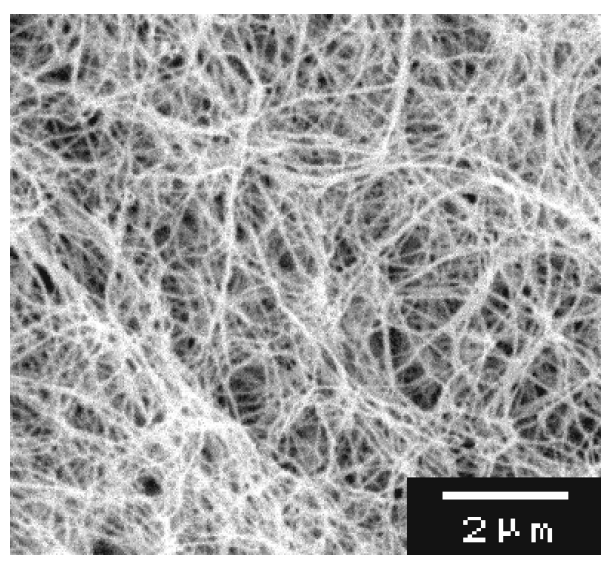

図 4 バクテリアセルロース 
これまでに，バクテリアセルロースシートにアクリル樹 脂，工ポキシ樹脂等の透明樹脂を含浸・硬化させることで， 纎維を 60-70\% も含有しながら，波長 $500 \mathrm{~nm}$ で約 $90 \%$ の光透過率を示す透明ナノコンポジットが得られている.

この透明材料は, シリコン結晶に匹敵する低い熱膨張係 数 $\left(3-7 \mathrm{ppm} /{ }^{\circ} \mathrm{C}\right)$ を有し, 鋼鉄並の強度 $(460 \mathrm{MPa})$, 高 弾性（30 GPa）で，かつフレキシブルであることから， ガラスの脆さ，ポリマーの高熱膨張を克服した新しい透明 素材として，幅広い用途への展開が期待できる.

\section{4 アカシア樹皮タンニンの利用}

アカシアは短期間で大きく成長する代表的な早生樹であ る. すなわち, 大気中の二酸化炭素を木質資源として固定 する能力に優れている. 現在, パルプチップ用に東南アジ アで広く植林されており，例えば，インドネシアのスマト ラ島南部には，19 万へクタール（東京都の面積に相当）に 及ぶアカシアマンギウムの大規模一斉産業造林がある。そ こでは植林から伐採まで 7 年間のローテーションで，年間 240 万トンの木材が生産されている.これは, 日本の木材 生産量の約 1 割にあたる.

その際問題となるのが，樹木の約 1 割を占める樹皮であ る. 現在, アカシアの樹皮は, パルプ原料として利用でき ないため大量に廃棄されているが, 矢野らは, アカシア樹 皮に大量のタンニンが含まれていることに着目し, その有 効利用について検討した. その結果, 樹皮を粉砕し, 篩に かけると, タンニンを 6 割以上も含む微粉末が約 5 割の収 率で得られることを見いだした。この微粉末は，木材を再 構築する際の接着剤に硬化促進剤として添加することが可 能で, ホルムアルデヒドのキャッチャー剂としても利用で きる. また, 適当な架橋剤を添加することで, 熱硬化性樹 脂の代替として利用できる可能性もある. 現在は, 夕ンニ ン高含有樹皮粉末の製造・販売を行う会社が関西に設立さ れ，樹皮粉末の様々な用途への展開を検討している.

\section{5 水分と熱が関与する木材レオロジー}

水分と熱が関与する木材レオロジーは, 木材の各種改良 法の基礎として重要であるが，これまで，高温での測定が 困難であったため $100^{\circ} \mathrm{C}$ 以下に限定して研究がなされてき た。師岡らは水分が関与する木材レオロジーの範囲を，一 気に $200^{\circ} \mathrm{C}$ まで拡大することをめざしている．水分状態の 異なる木材について $100^{\circ} \mathrm{C}$ 超温度域 (即ち過熱水蒸気雲囲 気）で, 応力ーひずみ関係, 応力緩和, クリープ, 圧縮変 形の固定化の程度 (回復度) などの力学挙動を測定し, そ れらと高温での化学構造変化との関係を検討している.こ れに関連して，過熱水蒸気を用いて木材を乾燥すると，条 件によっては乾燥応力が除去されることも見出している. 最近はさらに進んで, $100^{\circ} \mathrm{C}$ 超温度域での飽和あるいは各 相対湿度の過熱水蒸気雲囲気と平衡する木材の含水率を正
確に求め, $100^{\circ} \mathrm{C}$ 超温度域での各種の木材物性に及ぼす水 分の影響を明らかにしようとしている.

\section{6 機能性多糖の分子設計}

生理活性の強い糖の高分子である多糖は様々な機能を発 現することで知られているが，その主な特性は分子鎖の三 次元構造, 即ち多糖分子の周りの電子の存在確率の三次元 分布に伴うポテンシャル表面の形状に依存している.多糖 の示す代表的な機能としては, 植物体の骨格を形成する構 造機能, 貯蔵物質としてのエネルギーの蓄積機能, 生体に 於ける認識機能などがよく知られている。これらの機能は 多糖分子鎖が分子運動の過程で特定の三次元構造をとった ときに効率よく発現している，その構造の出現頻度を見積 もることのできる手法としては分子シミュレーションの応 用がある．田中らは，様々な多糖分子並びにその誘導体の 分子シミュレーションを通じて, 多糖分子鎖の示す機能と 構造の相関，更には多糖分子鎖と他の分子との相互作用を 解析し，新たな機能を発現する時のポテンシャル表面を予 測し, 新たな機能性材料を設計する研究に取り組んでいる。

\section{7 多糖及び多糖誘導体の構造解析}

田中らは，結晶による回折現象（X 線回折，電子線回折， 中性子線回折）と分子シミュレーションを組み合わせた， 分子モデル化法と呼ばれる解析法を用いて，多糖並びに多 糖誘導体の結晶構造解析を行うことにより, 多糖分子並び に多糖誘導体分子の絶対構造を決定する研究を行っている。 この手法は, 結晶構造解析に必要不可欠で, かつ極めて難 しい位相問題を回避することにより, 結晶構造解析を容易 に遂行可能にする手法である。これまでにガラクタンの結 晶構造解析, 並びに幾つかのセルロースエステル誘導体の 結晶構造解析にこの手法を適用して数々の成果を収めて きた。

\section{4.おわりに}

21 世紀に入り，資源・エネルギーの枯渴が深刻度を増 している. 地球温暖化等, 環境の危機的状況も顕在化して きた。これに対処する唯一の道は，環境保全と資源の持続 的利用を図る環境共生型社会への変革であり，それを支え るのは, 水と二酸化炭素から太陽の恵み(太陽エネルギー) によって無公害的に生産される植物資源である。全バイオ マス量の $99.9 \%$ を植物が占め，さらに，その約 $92 \%(1$ 兆 7,000 億卜ン）までが樹木であることを考えると，持続 可能な社会の基盤資源・材料として, 木材の重要性は, 今 後さらに増すであろう。生物機能材料分野では，これまで にない木材，植物資源利用技術の開発を，木材の構造，化 学と物性の関係に関する知見をもとに, さらに推進してい きたいと考えている. 